\title{
THE HARAM AL-ŠARĪF COLLECTION OF ARABIC LEGAL DOCUMENTS IN JERUSALEM: A MAMLŪK COURT ARCHIVE?
}

\author{
LA COLECCIÓN DE DOCUMENTOS LEGALES ÁRABES \\ DEL HARAM AL-ŠARĪF DE JERUSALÉN: \\ ¿UN ARCHIVO JUDICIAL MAMELUCO?
}

\author{
Christian MÜLler \\ IRHT (Section arabe), Paris
}

This article analyses the corpus of 900 documents in the Mamlūk Haram al-Šarîf collection from the angle of archival storage. The vast majority of these documents are linked to the Jerusalem judge Šaraf al-Dīn 'Īsā b. Ġānim and to his period in office between the years 793/1391 and 797/1395. The sample of surviving documents, primarily estate inventories but also a few documents from other areas of the law within the $q \bar{a} d \vec{\imath}$ 's competence, contradicts the assumption that the Haram corpus is a systematically compiled archive of $q \bar{a} d \bar{l}$ records. Court certifications of real-estate sales and further transactions that are preserved for other periods within the Haram corpus are totally absent for this particular period. There is, moreover, an abundant number of documents concerning financial transactions in institutions over which the judge had jurisdiction.

The necrology of the contemporary chronicler Ibn Hiğğ $\overline{1}$ (d. 816/1413) opens an interesting perspective to explain the selection of documents relating to Šaraf al-Dīn, who was involved in a massive corruption case.

Key words: Islamic Law; Archives; Arabic documents; Mamlūk Jerusalem.
Este artículo analiza el corpus de 900 documentos del Ḥaram al-Šarîf desde la perspectiva de la conservación de archivos. En su mayoría, estos documentos están relacionados con el juez de Jerusalén Šaraf al-Dīn 'Īsā b. Gānim y con el periodo en el que se mantuvo en el cargo, entre 793/1391 y 797/1395. La muestra de documentos estudiada, sobre todo inventarios de bienes, pero también documentos relacionados con otras áreas del derecho que pertenecen a la competencia del $q \bar{a} d \bar{l}$, contradicen la hipótesis de que los documentos del corpus del Haram al-Šarīf son registros del tribunal compilados sistemáticamente en un archivo. Los certificados judiciales sobre ventas de bienes inmuebles y otras transacciones que se han conservado de otros periodos en el corpus no aparecen precisamente para el periodo que va entre los años $793 / 1391$ y 797/1395. De esta época abundan también documentos relativos a las transacciones financieras realizadas dentro de instituciones para las que el juez tenía jurisdicción.

La necrología realizada por el cronista contemporáneo Ibn Hiî̀ŷ̀ (d. 816/1413) abre una perspectiva interesante para explicar la selección de documentos relacionados con Šaraf al-Dīn, que estuvo involucrado en un enorme asunto de corrupción.

Palabras clave: Derecho islámico; archivos; documentos árabes; Jerusalén Mameluco. 
The 900 documents of the Haram al-Šarif constitute the biggest collection of legal documents known today from the pre-Ottoman period. The documents are preserved as individual leaves of various sizes, mostly of paper although some contracts are written on parchment. ${ }^{1}$ Discovered in the years 1974 and 1976 at the Islamic Museum in Jerusalem, they were issued during the 8th/14th century, mostly in Jerusalem, or al-Quds al-Šarïf, as the city is known in the documents themselves. A chronological survey shows how unevenly they are distributed throughout the 8th/14th century. ${ }^{2}$ The lion's share of the texts are associated with the šāfi'‘ judge of Jerusalem, Šaraf al-Dīn 'İsā al-Hुazrağ̄i who died in Šawwāl 797/July-August 1395. These are documents which were issued during his period as judge, with or without his explicit command, or in which his name is mentioned in the text in some manner. ${ }^{3}$

This article asks whether these documents relating to the judge Šaraf al-Dīn ${ }^{4}$ constituted a typical $q \bar{a} d \vec{\imath} \vec{s}$ archive or might have been gathered for purposes other than archival conservation. ${ }^{5}$ Šaraf al-Dīn

${ }^{1}$ Cf. Little, D., Catalogue of the Islamic Documents from al-Haram aš-Šarîf in Jerusalem, Beirut-Wiesbaden, 1984. This article draws on my analysis of the Haramdocuments, entitled Qādī-Gericht und Rechtsadministration in Jerusalem. Studie der mamlukischen Dokumente des Haram Šarīf, Habilitationsschrift Halle, Wittenberg, 2007. This publication was prepared within the framework of the European Research Council's FP7 project "Islamic Law Materialized".

${ }_{2}$ The number of Arabic documents from before the year 700 amounts to 7; from between 700 and 709 there are 36 , for the twenty years $710-739,19$; for $740-749,16$; $750-759,10 ; 760-769,14 ; 770-779,30 ; 780-789,113 ; 790-799,579$. Most of our sources thus stem from the last ten years of the century, or even more precisely from the years 793 to 797 . [Note: In general, the dates given in the text are mentioned in higrri with their Christian correspondence, but not in the notes]

${ }^{3}$ Müller, C., "Le nom propre à géométrie variable: nommer et être nommé dans les actes du Haram al-Šarīf de Jérusalem (VIIIe/XIVe siècle)", in D. Aigle, C. Müller and M. Rouabah (eds.), Mélanges en l'honneur de Jacqueline Sublet, Damascus, forthcoming. Cf. Little, Catalogue, 9-12.

${ }^{4}$ We will leave aside other parts of the corpus, such as the 29 Persian documents (Little, Catalogue, 377-387), the corpus concerning individual persons and their estate, the 49 documents relating to the scholar Burhān al-Dīn (d. 789/1387), the 45 documents and (possibly) 45 account-sheets relating to the merchant Nāsir al-Dīn al-Hamawī (d. 788/1386), and a corpus of 27 witness-documents relating to villages administered by the waqfadministration of the Ḥaram al-Šarīf, dated 703-708, cf. Müller, Qädī-Gericht, chapter II.

${ }^{5}$ Donald Little considered them "remnants from the archives of a ... Shāfi ${ }^{\prime} \overline{1}$ judge" and wrote that "[a]s such, they constitute a variegated sampling of judicial and notarial documents, including court records, marriage contracts, wills, and financial records of various kinds", Little, D., "The Use of Documents for the Study of Mamluk History", Mamlük Studies Review, 1 (1997), 1-13, $11 \mathrm{ff}$. In the article Little, D., "Sidjill.2", El',

Al-Qantara XXXII 2, julio-diciembre 2011, pp. 435-459 ISSN 0211-3589 
was appointed šâfi $\overline{1}$ qã $\bar{l}$ of Jerusalem in Ramaḍān 793/August 1391. He stayed in office until his sudden death in $797 / 1395$, with an interruption of some months in the year 794/1392. ${ }^{6}$ For this period some 540 Haram documents exist, and some 40 further non-dated specimens may bear relation to persons who were active at the same time. ${ }^{7}$ The following survey identifies the types of documents from this period from the point of view of archiving. I will distinguish between "legal documents" that are signed by witnesses and constitute a legal instrument ( $h u \breve{g} \breve{g} a)$, and other writings such as petitions, correspondence, non-attested accounts, etc.

All the legal documents are written in a cursive hand in a regular block of text that is too dense to allow later additions but leaves some space at the right margin. The aim is obviously to prevent fraud. These two features of cursive handwriting and a densely written textblock make the opening word the most prominent and easily distinguishable. This is essential for classification and archival purposes where large numbers of documents are filed. The opening word of legal documents in the Haram corpus consists of a) the date, preceded by the formula bi-ta'rīh, or b) a verb designating a type of legal action, such as contracts (ištarā, ista' '̆ara), legal dispositions (awșā, asnada wașiyyatahu, yaqūl) or forms of evidence (šahida, aqarra, ašhada 'alayhi). The text form beginning with the demonstrative pronoun "this is", (hâd $\underline{a} \bar{a} m \bar{a}$ ištarā), exists in some older contracts in the Haram corpus, but does not occur in the documents dated between 793-797/1391-1395.

XIX, 539a, published in 1996, he more prudently describes the Haram collection as "[t] e closest approximation to a Mamlūk judicial archive". Frédéric Bauden considers

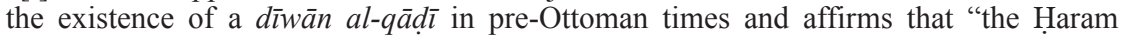
documents provide another proof for this", in Bauden, F., "Mamluk Era Documentary Studies: The State of the Art", Mamlūk Studies Review, 9 (2005), 15-60, 50. He is certainly right that the absence of archival documents is not evidence for the fact that they never existed. However, the survival of judicial and notarial documents as such is also no proof that they once constituted an archive, as will be shown in the present article.

6 The first inventory carried out under his command dates from 14 Ramaḍān 793 (not 794, as stated in Little, Catalogue, 105), cf. document no. 394. Muğīr al-Dìn, 'Abd al-Raḥmān al-'Umarī, al-Uns al-ğalīl bi-ta'rīh al-Quds wa-l-Halīl, Nağaf, 1968, 2:127, mentions him with the year 793 and his death in Šawwāl 797. His period as $q \bar{a} d \bar{\imath}$ is reconstructed according to preserved documents, cf. Müller, Qādì-Gericht, chapter III. The other judge in 794 was Taqī al-Dīn al-Bahnasī (not al-Barlasī, as stated in Muğīr al-Dīn, al-Uns al-ğalīl, 2:127), who ratified protocol no. 334, dated 25 Šawwāl 794.

7 Mainly concerning petitions and letters from a total of 87 undated sheets.

Al-Qanțara XXXII 2, julio-diciembre 2011, pp. 435-459 ISSN 0211-3589 
Chronological order is usually a primordial criterion for archival storage. Documents opening with a date ("protocol-form") within the Haram corpus contain reports on cases presided over by Šaraf al-Dīn ${ }^{8}$ concerning events following a "call for attestation" $(i s ̌ h \bar{a} d)^{9}$ or other events in court; ${ }^{10}$ one protocol concerns attestations linked to a homicide, ${ }^{11}$ and three others are protocols linked with events in court in earlier times. ${ }^{12}$ Protocols other than in the form of an $i s ̌ h \bar{a} d$ concern witnesses who were sent to the place of a crime (injuries), ${ }^{13}$ the sale of a crop of olives by the Hanqāh Șalāhiyya and the wages of workers,${ }^{14}$ and income from the harvest of a village for a foundation, ${ }^{15}$ whereas others are wills (wașiyya). ${ }^{16}$ The bulk of "protocols", however, consist of some 419 estate inventories of deceased persons and their legal heirs, drafted by the judge's command. These large numbers of documents open with the date and initially seem to substantiate the hypothesis of chronological archival storage. Systematic filing records can be found on the verso of some of these inventory protocols. ${ }^{17}$ However, the "protocol-form" of a document did not always take precedence over its content and was not the only way to notarize certain types of documents. This is illustrated by inventories which adopted another form: fourteen iqrār and six išhād documents on inventories open with the action aqarra or ašhada 'alayhi rather than the date. This second form, documents opening with a verb that designates the form of contract, legal dispositions and attestations, makes the general notion of archival storage by date more improbable. Most documents of this kind in the Haram corpus concern inheritance cases (see below).

${ }^{8}$ Nos. $031 / 1,032 / 1$ and $650 / 1$ on the same case; nos. 334, 648 and 649; other reports are nos. $653 / 1$ and $709 / 1$.

9 Nos. 606, 620.

${ }^{10}$ Nos. 500 and 615.

11 No. 30.

12 No. 018 , the forging of witness signatures; no. 336, a neighbour's permission for construction works and no. 191, the receipt of salaries.

${ }^{13}$ No. 642.

${ }^{14}$ No. 573 (from 789/1387).

${ }^{15}$ No. 763 (from 705/1306), Little, Catalogue, 376.

16 Nos. 501 and 659.

17 These registration marks contain elements on the name of the deceased, month of death and whether the heirs were present or absent, either written in full words or abbreviated, cf. Little, Catalogue, 62. See below.

Al-Qanțara XXXII 2, julio-diciembre 2011, pp. 435-459 ISSN 0211-3589 
Another important determining principle in archival storage can be the length of a document's legal validity. All the legal documents in the Haram corpus are basically "witness documents" in the sense that recorded facts are attested by at least two legal witnesses who personally sign their names below the text. In cases of litigation, the judge called upon these witnesses to attest orally to the content of the document. Only by this procedure of authentication could the judge acquire legal certainty ( $\underline{u} u b \bar{u} t)$ of its content and becomes able to certify to its authentication. Such a court-certified document then became valid as proof without the renewed oral attestation of its witnesses. The authentication procedure is notarized in the form of a "call for attestation" (išh $\bar{a} d)$ by the judge on the verso of the original document that was presented at court for certification. ${ }^{18}$ A simple "witness document" lost its potential value as a legal document if the witnesses were no longer able to attest orally, either because they were dead or absent, or when a new judge rejected them as honourable witnesses. As a consequence, such "witness documents" become mere paper after a relatively short period of time. Court-certified documents constituted "proof" for a longer period, and this rendered them more susceptible to archival storage.

However, only a small portion of the documents dated between 793-797/1391-1395 are court-certified and thus stayed valid for a longer time without further oral attestation. 20 documents exist which our judge Šaraf al-Dīn had certified by his court witnesses during his activity as judge in Jerusalem: five during the three-month period between Dū 1-Qa da 793 and Muharram 794/September and November $1391^{19}$ and thirteen from Rağab 795 until Rağab 797/May 1393 until May $1395 .{ }^{20}$ Three of these documents had been certified by judges officiating in other cities before Šaraf al-Dīn ratified them in

${ }_{18}$ Müller, C., "Écrire pour établir la preuve orale en Islam: la pratique d'un tribunal à Jérusalem au XIVe siècle", in A. Saito and Y. Nakamura (eds.), Les outils de la pensée. Étude historique et comparative des "textes ", Paris, 2010, 63-97.

${ }_{19}$ Išh $\bar{a} d$ in chronological order: nos. $610 / 2$ and $715 / 3$ from 15.11 .793 , no. $719 / 5$ from 20.11.793, no. 604/2 from 16.1.794 (the certified document was issued nine years earlier in 785 !) and no. $718 / 3$ from 19.1.794.

${ }^{20}$ No. 112/3 from 21.7 .795 , no. $707 / 3$ from 4.10 .795 , no. 647/2 from 11.12.795, no. $625 / 3$ from 24.12 .795 , no. $350 / 5$ from 2.1 .796 , no. $330 / 2$ from 22.2 .796 , no. $639 / 3$ from 1.4.796, no. $259 / 3$ from 26.4 .796 , no. $546 / 3$ from 1.3.797, no. 616/4 from 3.3.797, no. 356/1, from 17.3.797, no. 208/7 from 6.4.797 and no. $279 / 3$ from 3.7.797. 
Jerusalem, ${ }^{21}$ one by the hanafi deputy judge ( $n \bar{a}$ ' $i b$ al-hukm) of Jerusalem. ${ }^{22}$

As far as their contents are concerned, these documents certified at Jerusalem by Šaraf al-Dīn are associated mostly with deaths and inheritances: acknowledgements of debts, ${ }^{23}$ claims against a deceased person in the form of a witness attestation on the judge's order (mahdar) ${ }^{24}$ a reception of maintenance payment, ${ }^{25}$ a mahdar specifying that objects belonged to the deceased's wife and were not part of his estate, ${ }^{26}$ identifications of legal heirs in the form of mahdar documents, ${ }^{27}$ certifications of an estate inventory, ${ }^{28}$ a mandate to receive an inheritance ${ }^{29}$ or, finally, a certification concerning the estate of a Mamlūk emir from Damascus. ${ }^{30}$ Various other documents are also certified by Šaraf al-Dīn: the attestation that a real estate $(d \bar{a} r)$ was legally state property, ${ }^{31}$ the claim for a lost camel in the form of a mahdar document, ${ }^{32}$ and a marriage contract and subsequent repudiation. ${ }^{33}$ Certification may also be included in the witness document and attested accordingly, like the document on a will and subsequent actions. ${ }^{34}$ However, not all Jerusalem court certificates were effected by the $q \bar{a} d \bar{l} \bar{\imath}$ Šraf al-Dīn during that period. Three specimens bear the signs of certification by the šâfi ${ }^{1} \overline{1}$ deputy judge (halīfat al-hukm al(azìz). ${ }^{35}$

${ }^{21}$ Documents no. 350/3 (from 13.12.795) and no. 625/2 (from 14.12.795), were certified in Damascus by the šăfi ${ }^{i} i$ judge Ğamāl al-Dīn Muhammad al-Bahnasī, and no. 639/2 (from 25.3.796) by the judge of Ġazza, Šihāb al-Dīn Ahmad al-Salāwī.

${ }_{22}$ No. 208/6 (from 3.4.797).

${ }^{23}$ Nos. 112, 208, 350.

${ }^{24}$ Nos. 546, 616, 719 (the last two documents are deposits). On the "mahdar" see Asyūtịi, Ğawāhir al-'uqūd wa-mu'īn al-qudāh wa-l-muwaqqi' īn wa-l-šuhūd, M. 'Abd alHamīi al-Sa danī (ed.), Beirut, 1996, 2:362.

${ }_{25}$ No. 604.

${ }^{26}$ No. 611.

27 Nos. 279, 639 and 647.

${ }^{28}$ No. 259 (protocol-inventory); no. 707/1 (išhād-inventory), linked to inventory no. 262 and to no. 624 (mahdar). No. 715 (iqrär-inventory). The inventory no. 133/1 contains notifications to initiate the certification process, but the verso is empty. The case is linked to $i s ̌ h \bar{a} d$ no. 355 , receipt of money.

${ }^{29}$ No. 625.

${ }^{30}$ No. 356.

${ }^{31}$ No. 330.

${ }^{32}$ No. 718.

${ }_{33}$ No. 610.

${ }_{34}$ No. 644.

${ }^{35}$ Nos. 355/2, 611/3 and 624/3, all from the years 795 and 796 .

Al-Qanțara XXXII 2, julio-diciembre 2011, pp. 435-459 ISSN 0211-3589 
Certification may conserve legal validity over time,${ }^{36}$ or be indispensable to bring affairs to a conclusion. If the judge based his decision on a witness document, following procedural law that required oral proof, its authentication was obligatory. This is why debts or other claims against a deceased person - who could no longer be sued - were carried out through certified witness documents. If a debtor died without leaving a written acknowledgement (not so seldom in commercial relations), the creditor might present witnesses to the $q \bar{a} d \bar{l}$, who authorized a mahdar on his behalf. Once certified, this document became "proof", and thus allowed the judge to order the debt to be acquitted from the estate. ${ }^{37}$ Other certified documents concern the execution of an inheritance: some mahdar documents identify legal heirs, ${ }^{38}$ others are estate inventories ${ }^{39}$ or specify the mandate to receive an inheritance for minor heirs. ${ }^{40}$ Among all the certified documents of this 793-7/1391-5 period, only one specimen concerned the sale of real estate, ${ }^{41}$ whereas all the others were linked to the immediate execution of inheritances, separation after marriage, ${ }^{42}$ or the termination of a claim..$^{43}$ From all this, we conclude that the Haram documents of the 793-7/1391-5 period in their totality do not constitute either a chronologically organized archive or a deposit of court certificates for long-term use.

Non-certified witness documents from this period contain, among other things, wills (wașāya , s. wașiyya), ${ }^{44}$ records of the receipt of

${ }^{36}$ As was probably the case with the certified contracts of sales, nos. 15, 39, 42, $352,353,354,369,371,621,834,853$, dating between the years 710 and 785 , where no receipt of a claimed object is notarized; cf. Little, Catalogue, 275-295 (indicated for each document as $i \check{s} h \bar{a} d$ with witness clauses).

${ }^{37}$ Claim of debt from a deceased person: mahdar no. 546; nos. 616 and 719 concern deposits. In the same way, the mahdar containing the acknowledgement before death that certain items belonged to the deceased's wife, no. 611. It was necessary to establish a legal proof for the debt since refunding reduced the amount of an inheritance. Parts of absent heirs were deposited with trustworthy persons.

${ }_{38}$ Nos. 279, 639, 647, 654, and the already mentioned no. 611.

${ }^{39}$ Inventory no. $133 / 1$ is linked to išha $\bar{a} d$ no. 355, receipt of money; another case concerns inventory no. 262 and no. 624 (mahdar), a third example is no. 707/1 (išhäd).

40 The wakil receives money from an inheritance for minor heirs, no. 625.

${ }^{41}$ No. 330.

${ }^{42}$ No. 610.

${ }^{43}$ Cf. no. 718/4, the receipt for the lost camel.

${ }^{44}$ The following wills begin with a verb, not with a date: nos. 56, 544, 613, 633, 651, 849; also no. 340, where the date resembles no. 777 , but its witnesses acted in the 90 s and the cursive writing of seven and nine are very similar.

Al-Qanțara XXXII 2, julio-diciembre 2011, pp. 435-459 ISSN 0211-3589 
goods from a depository, ${ }^{45}$ sale protocols in the form of "final accounts" (mahzüma) concerning sales initiated by executors or the inheritance administration ${ }^{46}$ and other account sheets on estates ${ }^{47}$ and their sales. ${ }^{48}$ Several calculations of income-expenditures accounts from the office of escheat inheritance for the month Šawwāl 793/ September 1391 are also conserved. ${ }^{49}$ These documents are related to inheritances and their public administration by the Bureau of Escheat Estates (Dīwān al-Mawārīt al-Hašriyya). In this field the judge Šaraf al-Dīn played an essential role, since his tribunal notarized legal documents that were necessary for the execution of testaments and estates. However, the Haram papers concerning the public administration of inheritances only cover a very short period, the month Šawwāl 793/September 1391, and this is the only month for which documents exist from all four categories i.e. inventories, sale protocols, income-expenditures of the inheritance office and those of the Public Treasury (bayt al-māl). This is clearly a selection rather than a long-term archive.

The bulk of non-certified witness documents are estate inventories in the form of a protocol or as an iqrār- or išhadd-document. ${ }^{50}$ Were they part of a systematic archive in the Bureau of Escheat Estates, which became a kind of archive within an archive? Or had they been collected for other reasons? A closer look at their chronological distribution and physical aspects helps to find an answer to

${ }^{45}$ The iqrār of having received money, no. 312 due to a transfer of debt (hawāla), no. 325 (from the waqf of the deceased), no. 637. Deposit of items, no. 487, given back some months later, verso names the judge of Jerusalem. These documents were only certified in the case of a claim against the person receiving the deposit.

4622 documents during the years 793 to 797 : nos. 176, 177, 179, 480, 480, 531, 540, $579,580,581,586,589,590,591,593,767 \mathrm{t}, 767 \mathrm{j}, 768 \mathrm{a}$ followed by no. $768 \mathrm{~b}$ (nonattested), nos. 770a, 770b, 770h, 770h, 772a followed by no. 772b (non attested), no. 837a followed by no. 837b, [no. 539 is a "final account" of another kind], cf. Little, Catalogue.

47 Attested sheets are nos. 174, 564, non attested sheets nos. 178 and 182.

48 Attested sheet no. 530, non attested sheets nos. $770 \mathrm{j}$ and 582 .

49 Nos. 59, 175, 374 and 535, (partially edited by Richards, D., "The Mamlūk Barīd: Some Evidence from the Haram Documents", in A. Hadidi, Studies in the History and Archeology of Jordan III, Amman-London, 1982, 205-209, 208). These are directly linked to the "final accounts" of the same period, chronologically: nos. $770 \mathrm{j}$, 770b, 770h, 770a, 770h, as well as to expenditures nos. 770t, 104 and 770d. Cf. Müller, Qādī-Gericht, chapter V. 4.

${ }^{50}$ We count 373 "inspections" (wuqū $f$ ), 20 acknowledgements (iqrār), 24 calls for attestation $(i \bar{s} h \bar{a} d)$, one court record that includes the names of heirs, and 12 accounts of inventories (dabt).

Al-Qanțara XXXII 2, julio-diciembre 2011, pp. 435-459 ISSN 0211-3589 
this question. ${ }^{51}$ The first observation to be made in this respect is that the inventories preserved for this period are not complete. Several months are missing and the number of inventories per time period varies considerably: the very sparse inventories in the second half of the year 794/1392 $2^{52}$ correspond to a period when a judge other than Šaraf al-Dīn officiated in Jerusalem. ${ }^{53}$ For the rest of the 793-7/1391-5 period, the number of inventories during one month varies between only one or two specimens ${ }^{54}$ and as many as 35 inventories in Dū 1-Qa'da 795/September 1393. ${ }^{55}$ Such variation might be explained by the changing mortality rates during periods of Black Death in the city ${ }^{56}$ but it seems highly improbable that there would have been no deaths at all during certain months. And why should so many people have died from Šawwāl until Dū 1-Hiğğg 793/ September-November 1391, ${ }^{57}$ from Ramaḍān until Dū 1-Hiğğa 795/ July-October $1393,{ }^{58}$ as well as in Ramaḍān 796/May 1394, but very few in the year 797/1394-5 and none at all during the second half of the year 794/1392, which was a season of high mortality in other years? It seems very unlikely that the extant estate inventories are the set of a complete archive, or that mortality is the only reason for varying numbers.

${ }^{51}$ The survey on physical aspects was made possible thanks to a campaign to protect and photograph the documents, financed by the project "Islamic Law Materialized" and finished in March 2011. I would like to thank the Islamic Museum of Jerusalem and its director Khader Salameh for the complete set of images.

${ }_{52}$ Inventories are missing from Gumādā I 794 until the year 795 with two exceptions: no. 100 from 29 Ramaḍān, and no. 471 from 13 Dū 1-Hiğğg 794. Neither of these inventories mentions Šaraf al-Dīn's permission, so we do not know whether he or Taqī al-Dīn officiated (see below).

53 The judge Taqī al-Dīn al-Bahnasī ratified court decision no. 334 of 25 Šawwāl 794 as judge of Jerusalem. On this judge, see Muğ̄ir al-Dīn, al-Uns al-ğalīl, 2:127, confirming the year. The series of frequent estate inventories continues until 19 Rabīe II 794 (last inventory no. 520) and takes up again the 6 Muharram 795 (first inventory no. 612). Other periods without inventories do not exceed much more than two weeks.

${ }^{54}$ Only one inventory per month is preserved for $9 / 793$ (no. 394), 12/794, 5/795, $5 / 796$, and the months $3,5,6$ and 8 of the year 797. Two inventories exist from 10/796 and 2/797 and 7/797. See diagram in Müller, Qādì-Gericht, chapter V. 1.

${ }_{55}$ Other months with more than 25 inventories are 11/793, 12/793, and 12/795.

56 To use the inventories for population statistics is tempting but subject to many uncertainties. For example, dead children and slaves do not seem to have been considered.

57 Between 22 and 29 inventories each month.

${ }^{58}$ Between 20 and 35 inventories each month.

Al-Qanțara XXXII 2, julio-diciembre 2011, pp. 435-459 ISSN 0211-3589 
A second observation concerns the lack of a unique filing system for all inventories. As mentioned before, around 60 specimens bear a filing notation on verso. These notations may consist of a written phrase ${ }^{59}$ or, more commonly, the name of the deceased and an indication of the month and whether heirs are absent, present, or if the estate should go partially to the Public Treasury. ${ }^{60}$ Filing notations, if they exist, only record the month and never the year of the inventory. The most frequent notation, the $q \bar{a} f$ (for Dū l-Qa ${ }^{2} d a$ ), is used on 20 inventories of this month in the year $795 / 1393,{ }^{61}$ but not on the other 17 specimens. ${ }^{62}$ Specimens from the same month Du 1-Qa da in other years bear, however, no filing notation: either the verso is empty (30 documents from the year 793/1391) ${ }^{63}$ or no document from Dū l-Qa'da exists, as in the years 794/1392, 796/1394 and 797/1395. During the month Dū 1-Hiğğa 795/October 1393 the filing notation gim was used, ${ }^{64}$ but also al-hiğğa written as a word, ${ }^{65}$ and some specimens do not bear any filing notation. ${ }^{66}$ When the month is written out, indications on heirs are generally also indicated by a word, not a letter.

Thirdly, it is worth remarking on the lack of a standard paper format. This is true of the corpus overall, but also of shorter periods within it (see below). The most commonly used format is the daftar, a piece of paper that is a third higher than it is wide and which measures about $18 \times 26 \mathrm{~cm} .{ }^{67}$ These documents are usually folded twice

${ }^{59}$ Examples are nos. 89, 173, 248 and 443.

${ }^{60}$ Cf. Little, Catalogue, 62; either with the letter gayn or $h \bar{a}$ ', or the words $\dot{g} \bar{a}$ ' $i b$ (absent) or hädir (present). The letter $m \bar{\imath} m$ seems to indicate bayt al-māl, Public Treasury; cf. no. 493 and 845.

${ }^{61}$ See document nos. 81, 87, 130, 147, 156, 160, 378, 379, 388, 418, 429, 437, 493, $495,511,527,559,563,686$ and 733 .

${ }_{62}$ Nos. $60,127,139,200,259,384,400,431,452,472,503,515,523$ (its duplicate no. 559 bears a filing notation), 626, 657, 674 and 746 ,

${ }^{63}$ Documents (in chronological order): 152, 161, 877, 560, 159, 164, 725, 126, 84, $163,413,133,745,447,475,363,735,757,771 \mathrm{t}, 477,283,538,756,567,759,297$, 451, 91 and 638 .

${ }^{64}$ Examples are nos. 143, 261, 555, 656, 698 and 845.

${ }^{65}$ Examples are nos. 94, 124, 170, 254, 412, 432, 549, 720, 750, 760, 765 (eleven times out of 33 inventories).

${ }^{66}$ Nos. 123, 146, 247, 414, 434, 436, 441, 494, 548, 576, 632, 720, 754, 766 and 842.

${ }^{67}$ With a variation of plus-minus $0,5 \mathrm{~cm}$, the format applies to 74 documents. With a variation of $1 \mathrm{~cm}$ it includes 121 and with a variation of $3 \mathrm{~cm}, 170$ documents, nearly half the sample. In one case (no. 554), the same size is used as "landscape" format, folded along its width. 
along their height, resulting in four columns, and were bound together with a string that passed through four holes. Other inventories are written on a long and narrow format that is three times longer than it is wide, with a size of around $10 \times 28 \mathrm{~cm} .{ }^{68} \mathrm{~A}$ few inventories are written on a format that is a little less than two times higher than its width, with the size of some $12 \times 20 \mathrm{~cm}^{69}$ or, yet another type, in a format nearly as wide as it is high $(26 \times 28 \mathrm{~cm}) .{ }^{70}$ There are also some specimens of a different size ${ }^{71}$ that do not conform to this typology. Variations in paper size make it difficult to establish types of paper formats. As a general rule, the same proportions apply to slightly different sizes, not only to three or four standardized formats. With regard to the question of archival use it is important to make the following observation: within the same month, inventories bearing the same filing notation use various paper formats. ${ }^{72}$ From this we may conclude that the inventories were not drawn up on standard paper that was provided by an administration with a view to easy filing. Rather, we believe that notaries probably used their own paper.

Many inventories bear holes for a string to tie them together. ${ }^{73} \mathrm{~A}$ detailed analysis of paper formats, filing notation and existing holes makes it possible to reconstruct which specimens were grouped together physically at one time or another. This, however, changes nothing if we make the basic assumption that the totality of the inventories were not kept together before they found their way into the present "Haram corpus", as seems to be the case given that they do not have in common one unique filing method.

68 With a variation of plus-minus $3 \mathrm{~cm}$, it applies to 98 documents, but some documents of this proportion are even bigger.

69 Within plus-minus $3 \mathrm{~cm}, 15$ documents are included.

70 This format applies to even fewer documents: with a variation of plus-minus 3 $\mathrm{cm}$, there are only 4 documents (size between $23-29 \times 25-31 \mathrm{~cm}$ ), or with a size between 21-27 x 25-31, also 4 documents, but not the same.

71 Like the half format no. 435, or larger sizes, like the 19 documents higher than $35 \mathrm{~cm}$ and wider than 22: nos. 301, 338, 339, 344, 347, 612, 618, 626, 627, 634, 635, $641,656,657,705,707,711,713$ and 715 .

72 This can be demonstrated for the 38 documents of Dū 1-Qa da 795, with 20 specimens bearing the filing notation $q \bar{a} f$ : some are written on the long narrow format (nos. 81, 156, 378, 379, 388, 418, 429 and 437), others on the daftar format, (nos. 87, 130, 147, 493, 495, 511, 559, 563 and 733) and still others on a wide format (nos. 160, 527, no. 686). All daftar sheets are folded at least once in the middle and bear (at least) two holes right and left of the fold.

73 Little, Catalogue, 63-186, mentions some of them.

Al-Qanțara XXXII 2, julio-diciembre 2011, pp. 435-459 ISSN 0211-3589 
These observations on the physical shape and filing notations strengthen the hypothesis that these estate inventories were not created by a single administration with the intention of long-term archival use, since in that case standard paper sizes and filing notations would prevail. The "raison d'être" of these inventories was their use in an ongoing execution of inheritance within a relatively short period of some years, not to guarantee their perpetual conservation in an archive.

All of the Haram documents dated in the 793-7/1391-5 period are legal documents concerning claims against the deceased, executions of estates and the public administration of escheat inheritance. Some documents cover court cases, either as protocols or as certified witness documents. Only a few documents of this period are difficult to link to the judge Šaraf al-Dīn. ${ }^{74}$ However, two features argue against the hypothesis of an institutional $q \bar{a} d \bar{l}$ archive:

- The mixture of cases: certain fields of law, such as marriage, sales or criminal cases, are missing or are represented very scantily. If the Haram papers were the archive of the court in Jerusalem, we would expect to find reference to a very spectacular case that was reported in Mamlūk chronicles in D̄u 1-Hiğğa 793/November 1391: four Franciscan monks from the monastery of Zion had publicly insulted the religion of Islam, the Qur'ān and the Prophet Muhammad. After trial, they were imprisoned and eventually executed in accordance with a ruling by the Hanafi judge. The monks' exceptional, and for Muslim contemporaries incomprehensible, behavior found its way into the chronicle of Ibn Qādị Sunhba ${ }^{75}$ and was later also mentioned by Maqrīzī. ${ }^{76}$ In the Christian West, the monks were revered as martyrs. ${ }^{77}$ However, no Haram document makes any reference to this execution.

${ }^{74}$ These concern the marriage contracts no. 321 (with a repudiation), no. 646 (with a repudiation) and no. 302, as well as the lease of a vineyard, no. 629. All except no. 302 are signed by witnesses working also under Šaraf al-Dīn.

${ }^{75}$ Ibn Qāḍī Šuhba, Taqī al-Dīn Abū Bakr, Ta'rīhn Ibn Qādī Šuhba, 'A. Darwīsh (ed.), Damascus, 1977-1997, 3:389f., on Dū 1-Hiğğa 793.

${ }^{76}$ Maqrīzī, Taqī al-Dīn Aḥmad, Kitāb al-Sulūk li-ma'rifat duwal al-mulūk, S. 'A. 'Āšūr (ed.), Cairo 1970, III, 2 (783-801), 3:792, during the year 795. Was this a second group of monks?

77 Heullant-Donat, I., "Les martyrs franciscains de Jérusalem (1391), entre mémoire et manipulation" in D. Coulon et al. (eds.), Chemins d'outre-mer. Études d'histoire sur la Méditerranée médiévale offertes à Michel Balard, Paris, 2004, 439-460, whom I thank for this information. 
- The number of personal and selected documents that concern the judge personally: all the contracts of the 793-7/1391-5 period have the judge Šaraf al-Dīn as the concluding party. ${ }^{78}$ Various documents from an earlier period also concern him or property transfers within his family. ${ }^{79}$ Other documents reflect his activity as judge in Nablus during the years 782-786/1380-1384. ${ }^{80}$ Various documents on payments and obligations name him as judge of Jerusalem and administrator of the city's foundations. ${ }^{81}$ The judge was renowned for his initiative of turning the agricultural lands of the Biqaa-plain south of the city into hikr-land, thus increasing the foundations' revenues. ${ }^{82}$ Šaraf al-Dīn was also administrator of the Șalāhiyya-Hูannqāh, ${ }^{83}$ a position previously held by his father. ${ }^{84}$ Various accounts attested by witnesses ${ }^{85}$ or not, ${ }^{86}$ as well as legal documents ${ }^{87}$ concern this activity. In addition, we find some missives addressed to the judge and papers lodging complaints or reclaiming borrowed objects. ${ }^{88}$ We also have an estate inventory con-

${ }^{78}$ He rents out a shop in Nablus (no. 499), he buys a horse (no. 324, from 1.7.797), and another (no. 267, from 2.7.797), cf. Little, Catalogue, 281 and 284.

${ }^{79}$ Müller, Qādì-Gericht, chapter II. 6b. These concern documents no. 608 (transfer of property of five shops in 779) and no. 660 (parental links within his family). A link by names may be established for no. 28 and no. 29. The $q \bar{a} d \vec{\imath} \vec{s}$ father rents out a hammām in 747 (no. 46).

${ }^{80}$ Müller, Qādì-Gericht, chapter II. 4.

${ }^{81}$ Išh $\bar{a} d$ no. 492 contains the villagers' obligation to deliver barley to the judge. Receipt of money (uğra) paid by judge, no. 105.

${ }_{82}$ Muğ̄ir al-Dīn, al-Uns al-ğalīl, 2: 127, translated in Little, D., "Two FourteenthCentury Court Records from Jerusalem Concerning the Disposition of Slaves by Minors", Arabica, 29 (1982), 16-49, 24, with the year 793 as the date for this change.

${ }^{83}$ See the undated document no. 620: another šayh renounces as head of the Hānqāh Salāhiyya, cf. Little, Catalogue 10 and 266. In the year 792 he is named as šayh alḨānqāh al-Ṣalāhiyya, no. 18.

${ }^{84}$ Cf. no. 46 , a lease contract from the year 747 .

${ }^{85}$ No. $773 \mathrm{a}$. No. $773 \mathrm{~b}$ is probably its continuation.

${ }^{86}$ No. 534: the šayh of this Hānqāh, Šaraf al-Dīn, sells the estate of a deceased șūfî, non attested accounting. Several accounts of the Salāhiyya foundation: no. 774a (revenues of the Hānqāh Șalāhiyya in Dū l-Qa da 791), no. 775a and no. 775b, in the same hand, contain the listing of sales, the other leaves, no. 775t, no. 775th and no. 775j are without preamble but have a similar content.

${ }^{87}$ No. 573 is a protocol on the sales of olives from the Biqaa-area from 789 in favour of the Hāanqāh Șalāhiyya foundation. A possible link to the judge Šaraf al-Dīn is that he converted the Biqaa-land into vineyards (kurūm) in the year 793, cf. Muğìr al-Dīn, al-Uns al-ğalīl, 2:127.

${ }^{88}$ See infra.

Al-Qanțara XXXII 2, julio-diciembre 2011, pp. 435-459 ISSN 0211-3589 
cerning him, dated on 2 Dū 1-Qa da 797/19 August 1395, soon after his death. ${ }^{89}$

Since the bulk of the 793-7/1391-5 period documents concern his function as judge, the idea of a private archive is hardly conceivable. The lack of coherence within archival material of different types, coupled with the corpus's concentration on the person of a single judge remains a mystery that calls for an explanation. And why were the documents preserved next to the Sanctuary of the Aqșā Mosque, in what much later became the Islamic Museum of Jerusalem?

The situation calls for a different kind of explanation. What if the Haram documents of the years 793-7/1391-5 were not compiled by S̆araf al-Dīn himself, but were put together in order to build up a dossier against him and his administration? If the preserved documents were not his archive but part of a corruption case, then the interpretation of some documents is given another twist. Among the preserved papers are petitions to the judge, complaints against him, ${ }^{90}$ administrative missives from and to the viceroy and other dignitaries or from subordinates, ${ }^{91}$ but also aborted cases, like those mahdar documents that were never certified because the witnesses had not been accepted. ${ }^{92}$ We must assume that the latter were formally correct, but were they really justified?

A short text passage by the historian Ibn Hiğğ $\overline{1}$, announcing the judge's death at the beginning of Šawwāl 797/20 July 1395, nour-

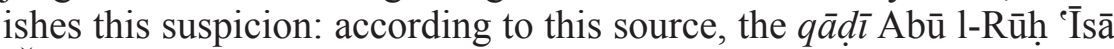
(Šaraf al-Dīn) was known for his bad conduct (sayy' al-sìra). He enriched himself in collaboration with the major-domos of the sultan, Mahmūd, from the assets of the foundations and the property of the notables. The inhabitants of Jerusalem repeatedly complained to the

89 No. 498.

${ }^{90}$ Undated complaint that the (unnamed) šafíi 1 judge certified a wașiyya only on payment of 200 dirhams, no. 275.

${ }_{91}$ The Chief Judge of Damascus orders Šaraf al-Dīn to draw up a mahdar in favour of the foundation Ḥusām al-Dīn Barke Hुān, no. 36 (dated 797). For other missives see below.

${ }^{92}$ The procedure of certification of the acknowledgement of debt in no. 345 had begun with the claimant's oath (no. 345/2). The witnesses considered "honourable" had attested, but the document bears no certification. The identification of legal heirs (no. 654), was not certified since the witnesses were not considered "honourable". On this procedure for evaluating witnesses $($ raqm li-l-šshūd), see Müller, "Écrire pour établir la prevue", 72 and 76.

Al-Qanțara XXXII 2, julio-diciembre 2011, pp. 435-459 ISSN 0211-3589 
authorities, among others to the newly nominated Chief Judge Sariyy al-Dīn [in Damascus] who tried to intimidate him (yuhaddiduhu). However Šaraf al-Dīn was struck by colitis (qūlanğ) and died the same day that a letter from the sultan in Cairo arrived. This letter ordered an investigation of his case and a public flogging of the judge at the Haram sanctuary. ${ }^{93}$

The above-mentioned Sariyy al-Dīn can be identified as the judge of Damascus Abū 1-Hatțāb Muhammad b. Muḥammad b. 'Abd alRahīim b. 'Alī b. 'Abd al-Malik al-Maslātī (751-799/1350-1396). ${ }^{94} \mathrm{He}$ was nominated Chief Judge of this city in Ramaḍān 797/June 1395, probably during a stay in Jerusalem. ${ }^{95}$ Sariyy al-Dīn was well known in Jerusalem, where he held several permanent offices after 795/1391$2 .{ }^{96}$ This might explain why the citizens of this city directed their complaints to him even before he was formally invested in his new post in Damascus in the end of Šawwāl 797/August 1395. During the years $795 / 1391$ to $797 / 1394$, he frequently travelled to Jerusalem, ${ }^{97}$ while being temporarily replaced in his Damascene teaching positions, ${ }^{98}$ which he continued to hold. ${ }^{99}$ With his nomination as Chief Judge in

${ }^{93}$ Ibn Hiğğḡi, Šihāb al-Dīn Abū l-'Abbās Ahmad al-Sa dī al-Husbānī, Tā'rīh Ibn Hiğğğ $\bar{l}$, Abū Yahyā 'Abd Allāh al-Kundarī (ed.), Beirut, 1424/2003, 1:131, shorter in Ibn Qāḍī Šuhba, Ta'rīh, 3:565. Ibn Hağar al-'Asqalānī, Inbā' al-Ġumr bi-abnā al-'umr, Beirut, reed. 1986, 3:269, only names the judge and his date of death.

${ }^{94}$ Ibn Qāḍi Šuhba, Ta'rīh, 3: 642f. for his necrology, ibid, passim, for stages in his career since the year 777 .

${ }^{95} \mathrm{Ibid}$., 555, 642. In Damascus, his nomination was announced after his departure to Jerusalem on Saturday, 13 Ša 'bān 797, Ibn Hị̆ğği, Tã'rīh, 1:123. This cannot refer to

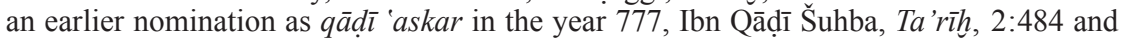
$3: 671$, and in 782 , ibid., $3: 36$.

${ }^{96}$ From the end of the year 795 on, he gave the Friday sermon (hitāba) at the Aqșā Mosque and replaced Nağm al-Dīn Ibn al-Ğamāea in certain posts, Ibn Qāḍī Šuhba, Ta'rīh, 3:475 1. 19f., 477 1. 7, and 642. Before that he had replaced Ahmad b. 'Umar b. Muslim (d. 793) as Friday preacher, ibid., 391. The data given by Muğīi al-Dīn, al-Uns al-ğalīl, 2:137, is approximate.

${ }_{97}$ In Dū 1-Hịğğa 795, Ibn Qāḍī Šuhba, Ta’rīh, 3:475, departure 1 Rabī' I 796, Ibn Hị̆ğḡi, Tà'rīh, 1:44, in Rabī' II 796, Ibn Qāḍi Šuhba, Ta'rīhn, 3:504 1.7, end of Muharram 797 during the sultan's visit in Jerusalem, he was present as hațīb and imām of the al-Aqșā

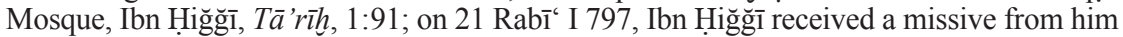
from Jerusalem that designated a replacement for his teaching obligations in Damascus, ibid., 100. On 17 Ša ‘bān 797 he reached Damascus from a stay in Jerusalem, ibid., 117.

${ }_{98}$ Cf. ibid., 100. In other contexts, Ibn Hiğğ $\overline{1}$ enumerates his teaching positions at the Madrasa al-Šāmiyya al-Barrāniyya, the Madrasa al-Šāmiyya al-Ğawāniyya, the Rukniyya, etc.

${ }_{99}$ When Ibn Qāḍ̄ Šuhba taught in Ša bān 797 at the Madrasa Ṭabariyya, Sariyy al-Dīn was present, Ib̉n Qāḍi Šuhba, Ta'rīhn, 3:551.

Al-Qanțara XXXII 2, julio-diciembre 2011, pp. 435-459 ISSN 0211-3589 
Damascus in Šawwāl 797/August 1395, he also became the Friday Preacher in that city and was replaced in the Aqșā Mosque of Jerusalem. ${ }^{100}$ Around the time of Šaraf al-Dinn's death at the beginning of Šawwāl 797/August 1395, the designated Chief Judge of Damascus might well have stayed in Jerusalem, ${ }^{101}$ his return from this city to Damascus being dated on the 26 Šawwāl 797/14 August 1395. ${ }^{102}$

One explanation for the Haram corpus would be that Sariyy al-Dīn collected documents to enable judicial appeal in some cases, presumably to give some of Šaraf al-Dīn's victims the opportunity to stake their claims. He might also have been trying to make enquiries about the dead judge's personal property, in order to find out whether it was legally acquired or not. All this would explain the existence in the corpus of certain complaints, petitions and aborted cases, as well as the documents on Šaraf al-Dīn's contracts and family property. In addition, this hypothesis of judicial appeal in cases that the corrupt Šaraf al-Dīn had decided upon or refused to accept, provides a convincing explanation of the fact that the preserved documents touch on various aspects of cases, including their preliminary stages, and not only final decisions in court cases that were filed away in an archive.

One striking example of this concerns Muhibb al-Dīn Ahmad, son of the former Chief $q \bar{a} d \bar{l}$ Burhān al-Dīn Ibn al-Ğamāea. Document no. 706, dated during the last decade of Muharram 797/October 1394, describes how the estate of the late Muhibb al-Dīn (d. 795/1391-2) (103 $^{103}$ was handed over to an envoy of Mahmūd, major-domus of Egypt. This happened, according to our document, in fulfillment of an order signed by Mahmūd and the Chief Judge of Egypt, Badr al-Dīn, which was addressed to the Jerusalem judge Šaraf al-Dīn. ${ }^{104}$ In addition, we have three specimens of a court record from Safar 797/November

100 Ibn Hiğğ̄̄in, Tā'rīh, 1:123.

101 As stated above, he is reported to have left Damascus for Jerusalem before Sat-

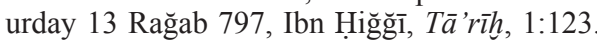

${ }_{102}$ Ibn Hiğğ̄i, Tà'rīh , 1:130; "the last day of the month": Ibn Qādī Šuhba, Ta'rīh, 3:555, both in connection with his investiture in Damascus.

${ }^{103}$ Muğìr al-Dīn, al-Uns al-ğalīl, 2:108. Cf. Salibi, K., "The Banū Ğamāea. A Dynasty of Šăfi ite Jurists in the Mamluk Period”, Studia Islamica, 9 (1958), 97-109, 105.

${ }_{104}$ These books sent to Cairo were then bought by Mahmūd, who gave them to his Madrasa as a foundation. See Ibn Qāḍi Šuhba, Ta'rīh, 3:645, 1. 1f., referring to the books "of Ibn al-Ğamā'a after his death", in a marginal note in the autograph, Istanbul, As'ad Efendi, no. 2345 (to this ms. cf. ibid., 2:57-61). 
1394 on the $q \bar{a} d \bar{\imath}$ 's decision partially to invalidate the will of this same Muhibb al-Dīn. ${ }^{105} \mathrm{~A}$ further document informs about the receipt of a missive (mukātaba) from Šaraf al-Dīn concerning the $q \bar{a} d \vec{\imath} \vec{\imath} \mathrm{s}$ actions in the Muhibb al-Dīn inheritance case. ${ }^{106}$

The missive, document no. 24, from Šawwāl 796/September 1394 from the "Mamlūk Mahmūd" to the $q \bar{a} d \bar{l} \bar{\imath}$ Šaraf al-Dīn mentions the Chief Judge of Egypt Badr al-Dīn and thus illustrates the connection between these men. This case is even more relevant to our analysis of how the corpus was collected and preserved, since the (supposed) investigating judge Sariyy al-Dīn was himself personally involved in the case: Muhibb al-Dīn's father, the former Chief Judge Burhān alDīn Ibn Ğamā’a was also the father-in-law of Sariyy al-Dīn. ${ }^{107}$ Sariyy al-Dīn had replaced Nağm al-Dīn Ibn Ğamāea, the stand-in for the minor Muhibb al-Dīn, ${ }^{108}$ in various offices in Jerusalem from the year 795/1391-2 onwards, when Nağm al-Dīn travelled to Cairo to renew his appointment but died before his return. ${ }^{109}$

Another legally dubious case concerns the estate of the former šayh Muḥammad-Bāk Zāwiya, Yahyaā b. Husayn b. Zakariyā', whose inheritance was sold on 12 Dū l-Qa'da 793/11 October 1391 and produced a revenue of 487 gold mitqāl which was subsequently handed over to the emir Balāt, a follower of the major-domus Mahmūd. ${ }^{110}$ Several documents prove that this transfer of money to Egypt was precipitate: an estate inventory of the deceased was dated 13 of Du $1-Q a^{\circ} d a,{ }^{111}$ one day after a part of the estate had already

${ }^{105}$ Nos. 31, 32 and 650. Document no. 650 was edited by Little, "Two FourteenthCentury Court Records", no. 32 by 'Asalī, K.Ğ., Watāa 'iq maqdisiyya ta 'rīhiyya, Amman, 1983-5, 1:221 (no. 26).

106 No. 704. Cf. Little, Catalogue, 375. Reference to the certification of Muhibb al-Dīn's will in Hebron is written upside down in the right margin.

${ }^{107}$ Ibn Qādī Šuhba, Ta'rīh, 3:642: in 776 he was the stand-in for his father-in-law Ibn Ğamāea as $q \bar{a} d \bar{l}$ in Cairo. If this Ibn Ğamāea was indeed Burhān al-Dīn Ibrāhīm b. 'Abd al-Raḥmān Ibn al-Ğamāe a, the father of Muhibb al-Dīn, then Sariyy al-Dīn was married to a half-sister of the latter. In any case it is clear that he was closely linked to the Banū Ğamāea.

${ }^{108}$ Muğīr al-Dīn, al-Uns al-ğalīl, 2:108. cf. Salibi, “The Banū Ğamāea”, 105.

109 In D̄u l-Qa'da 795 he replaced Nağm al-Dīn Ibn Ğamāea in all his posts except the teaching position at the Madrasa al-Ṣalāhịyya, Ibn Qāḍi Šuhba, Ta 'rīh , 3:475/1. $19 \mathrm{f}$. and 496, a post given to Šams al-Dīn Ibn al-Hazrağì, ibid., 477 1.5-6 ; cf. Muğīir al-Dīn, al-Uns al-ğalīl, 2:108f. On Nağm al-Dīn see also Maqrīzī, Kitāb al-Sulūk, III, 2:795.

${ }_{110}$ See no. $768 \mathrm{a}$ and $768 \mathrm{~b}$. 487 corresponds to the number given as a total - the finally transferred sum has to be calculated according to both lists.

${ }^{111}$ No. 178.

Al-Qanțara XXXII 2, julio-diciembre 2011, pp. 435-459 ISSN 0211-3589 
been sold and transferred to Egypt. Another person reclaimed some objects that had been deposited with the deceased šay "in the middle decade" of the same month, and these objects were handed back after the plaintiff's oath and juridical certification on 20 Du 1-Qa da. ${ }^{112}$

Here again, we encounter the name of Mahmūd the major-domus of Egypt ${ }^{113}$ the man Ibn Hiğğ $\overline{1}$ claimed had collaborated with the corrupt judge Šaraf al-Dīn. Maḥmūd was a very influential individual in the entourage of the sultan Barqūq. Soon afterwards, however, he fell into disgrace and was removed from his office in Safar 798/ November-December 1395, ${ }^{114}$ just a few months after the death of judge Šaraf al-Dīn. Maḥmūd's hidden treasures were successively recovered ${ }^{115}$ and he died in prison on Sunday 9 Rağab 799/8 April 1397. ${ }^{116}$ The search for this hidden money might have had consequences on a smaller, local scale and could have led to investigations concerning documents issued under the deceased $q \bar{a} d \bar{l}$ Šaraf al-Dīn, but this particular link is less certain.

Missives involving the judge Šaraf al-Dīn, the viceroy of the city (nä'ib al-saltana) and other dignitaries, constitute other categories of preserved documents. Five missives by Mamlūk officials are addressed to the $q \bar{a} d \bar{\imath}$ Šaraf al-Dīn during the year 796/1392-3. ${ }^{117}$ A sixth such document only bears the month and not the year. ${ }^{118}$ One common feature in these missives is that the expeditor is identified as a

${ }_{112}$ See the various notarisations in document no. 719, cf. Little, Catalogue, 49ff, not edited.

${ }_{113}$ On his career, see Broadbridge, A.F., "Royal Authority, Justice, and Order in Society: The Influence of Ibn Haldūn on the Writings of al-Maqrīzī and Ibn Tagirībirdī", Mamluk Studies Review, 7 (2003), 231-245, esp. 237ff. For indications concerning his career see Maqrīzīi, Kitāb al-Sulūk; cf. Ibn Qād̄ị Šuhba, Ta'rīh, 3: passim.

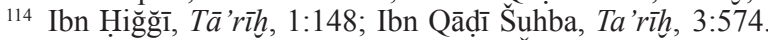

115 Ibn Ḥiğğ $\overline{1}, T a \bar{a}$ rīh, 1:161; Ibn Qàdẹi Šuhba, Ta'rīhn, 3:573, 578; Maqrīzī, Kitāb al-Sulūk III, 2:839f., 850f., 856f., 861, 885.

${ }^{116}$ Cf. Ibn Hị̆ğği, Tā'rīh, 1:227f., partially cited by Ibn Qāḍ̄ Šuhba, Ta'rīh, 3:574, 578, Maqrīzì, Kitāab al-Sulūk III, 2:885, who gives the day of his death.

117 Document no. 68 is probably the oldest and dates from the beginning of Ğumādā II. It was sent by the "mamlūk "Abd al-Rahmān", and three others by "almamlūk Aḥmad", who can be identified as Aḥmad al-Yaġmūrī, viceroy of Jerusalem (no. 023, from 27 Ğumādā II announces his nomination as nā'ib al-salțana; no. 602, from 12 Gumādā II concerns affairs in a village; no. 599 from 12 Šawwāl 796, covers financial matters). There is a fifth missive from Šawwāl 796, no. 024, sent by "al-mamlūk Mahmūd", cf. Little, Catalogue, under the respective numbers, not all readings are confirmed.

${ }^{118}$ No. 70.

Al-Qanțara XXXII 2, julio-diciembre 2011, pp. 435-459 ISSN 0211-3589 
Mamlūk officer by use of the nisba "al-malakī al-zeăhirī" (referring to the sultan al-Zāhir Barqūq) below the invocation of God (basmala). ${ }^{119}$ The addressee is given as al-šarafì, i.e. Šaraf al-Dīn, in the right margin above the first line of text. ${ }^{120}$ Another specimen, document no. 36, is a formal order by the Chief Judge of Damascus to Šaraf al-Dīn concerning the foundation of Husām al-Dīn Barke Hān.

Other letters to judge Šaraf al-Din were written by non-identifiable individuals. Two texts were addressed to the judge using the nisba "al-šaraf $\bar{\imath}$ " by individuals who were not Mamlūk officers. ${ }^{121}$ No. 841 is addressed on the back to al-Šarafì b. Gānim, and informs the $q \bar{a} d \bar{\imath}$ of the cultivation of lands belonging to the Șalāhiyya foundation.

Document no. 71 is written by a clerk and addressed to an unnamed third person. It demands that the "judge 'Īsā b. Gānim" hand back the carpets that he had taken from the Dome of the Rock. ${ }^{122}$ Ġāliya bint 'Uțān addressed a petition which, as usual, is undated, to the judge Šaraf al-Dīn in which she asked that her deceased father's family foundation be respected. ${ }^{123}$ This petition was definitely written after Dū 1-Qa da 795/September 1393, the date of her father's estate inventory. ${ }^{124}$ Other undated documents referring to šarafi or to a judge may well have a connection to the $q \bar{a} d \bar{\imath}$ Šaraf al-Dīn. ${ }^{125}$ Without further information or details, and since we do not know which documents were kept together in the past - they were, after all, only found together in 1974 and $1976^{126}$ - we will not press interpretation or consider these specimens in the following conclusions.

119 Cf. Qalqašandī, Șbh al-a šă fì șanā'at al-inšā', Cairo, 1913-19, 8:55, 1. 11f. and 6:194, cf. Müller, Qādì-Gericht, chapter I.2.e.3 "Ehrerbietende Schreiben".

${ }_{120}$ Cf. Diem, W., Arabische Geschäftsbriefe des 10. bis 14. Jahrhunderts aus der Österreichischen Nationalbibliothek in Wien, Wiesbaden, 1995, 1:206f., for the two cases, a nisba designating sender or addressee.

${ }^{121}$ No. 235, informing about a problematic case and asking for help, without being a formal petition; and no. 272 dated from 794 (contrary to Little, Catalogue, 42, and Richards, "The Mamlūk Barīd", 208), partially edited in Richards, "The Mamlūk Barīd", 208.

${ }^{122}$ Cf. Little, Catalogue, 40.

${ }^{123}$ No. 278. Apparently, the judge did not react by making a decree. The accounting on verso concerning "Hạăğg 'Uțmān" may refer to her father's heritage.

${ }^{124}$ Cf. nos. 515 and 626.

${ }^{125}$ For example, nos. 213 and 221.

${ }^{126}$ Little, Catalogue, 1. In their first article, Northrup, L. and Abul-Hajj, A.A., "A Collection of Medieval Arabic Documents in the Islamic Museum at the Haram alŠariff", Arabica, 25 (1978), 282-291, describe the first 50 documents (Little, Catalogue, nos. 1-50), out of a total of "354 complete documents as well as many other small fragments" (p. 283). This article was prepared in spring 1976, i.e. before the second 
Among the Haram documents issued under Šaraf al-Dīn's $q \bar{a} d \bar{l}-$ ship there are hundreds of estate inventories and some other protocols, plus various legal documents concerning inheritance and related issues, as well as various account sheets arising from his activity as judge. The 431 estate inventories, however, are not a complete set for the covered period, since certain months are missing, ${ }^{127}$ and they do not follow a unique filing system. We concluded from this that the Haram documents were not a systematic archive to which other documents where added, but rather a selection from the Bureau of escheat inheritances and from other places which were gathered together in order to carry out an enquiry.

Why then did this selection of documents concerning an affair that was not destined for archiving stay together, and why were the documents not destroyed when the affair was closed? The simple answer to this is that there are reasons to believe that the affair was probably never closed - at least not if it was the Damascene judge Sariyy al-Dīn who led the enquiry and was the driving force behind the collection of the papers. After Sariyy al-Dīn left Jerusalem at the end of Šawwāl 797/mid July 1395 to take up his office as judge of Damascus, there is no indication that he returned to the city. He remained in office in Damascus until 1 Ğumādā 799/February-March $1397 .{ }^{128}$ We dispose of abundant information written by his deputy $(n \bar{a} ' i b)$, the historian Ibn Hiğğ $\overline{1}^{129}$ concerning his other travels, illnesses, etc, but no mention is made of his return to Jerusalem during this period. ${ }^{130}$ Latter Sariyy al-Dīn is said to have settled in Jerusalem "around one and a half years after his nomination in Damascus"131 - a time - span that corresponds roughly to the end of his mandate

discovery of documents in October 1976 (cf. Little, Catalogue, 1). Referring to this second discovery, the two authors indicate "since then the existence of still other documents has become known" (p. 283). Assuming that the 354 complete documents were numbered successively and that they correspond to the numbers 1-354 in the Catalogue, we conclude that higher catalogue numbers refer to documents in the second finding. If this is so, it can be assumed that the documents from 793-797 examined here came from the two distinct findings and were not stored in the same place.

${ }^{127}$ See above. The inventory is missing for at least one deceased person during that period, i.e. Muhibb al-Dīn.

${ }^{128}$ It is unclear whether this refers to Ğumādā I (February 1397) or to Ğumādā II (beginning on 2 March 1397).

${ }^{129}$ On Ibn Hiğğğ̀’’s appointment cf. Ibn Qāḍī Šuhba, Ta'rīh, 3:555, 1. $14 f$.

${ }^{130}$ Ibn Hiğğgì, Tà'rìh , vol. 1, passim.

${ }^{131}$ Ibn Q̄àḍ̄ Šuba, Ta'rīh, 3:642.

Al-Qanțara XXXII 2, julio-diciembre 2011, pp. 435-459 ISSN 0211-3589 
in Damascus. This is when he could have taken up the enquiry again, at a time when the former major-domus Mahmūd was already in prison. However, soon after this the judge received orders to go to Cairo, where he died on 16-17 Rağab of the same year/15-16 April 1397. ${ }^{132}$ This meant that within less than two years after the inglorious death of Šaraf al-Dīn, his major accomplice as well as the inquisitor were both also dead - and interest in pursuing the affair almost certainly diminished, even though the case had yet to be resolved. As a former preacher at the Aqșā Mosque, Sariyy al-Dīn may well have deposited the "Haram documents" before his departure for Cairo in a place where his successors and guardians ordered them to be kept or forgot about them, and where they survived together with other items for the next 600 years, until their re-discovery in the $20^{\text {th }}$ century.

If this reconstruction is more or less correct, the Haram documents did not escape destruction because they were destined for archival storage, but because circumstances prevented the conclusion of an ongoing judicial enquiry which would have ended with the destruction of all auxiliary documents. This would provide a very good explanation of the specific character and composition of the surviving corpus. The long-term preservation of this unique collection was, then, almost certainly due to a combination of lucky circumstances i.e. the early death of all parties concerned, which is to say the corrupt judge, his accomplice, and the investigator. For this reason, the affair was held in suspense, and was never closed by destroying all unnecessary documents. Finally, the corpus was deposited in a place, the Haram al-Šarif of Jerusalem, where unused documents could last for centuries without significant damage.

The Haram documents teach us a great deal about Mamlūk legal practice. The question of what constituted a pre-Ottoman dīwān al$q \bar{a} d \bar{l}^{133}$ however, cannot be answered by reference to this material. If

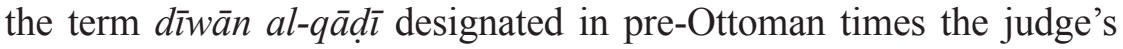
archive for his personal use whilst in office, it is conceivable that the

132 Ibn Hiğğḡi, Tà'rīh, 1:228, cf. Ibn Qāḍi Šuhba, Ta'rīh, 3:642, also Ibn Tag̉rībird̄̄, al-Nuğūm al-zăhira fì mulūk Miṣr wa-l-Qähira, Cairo, s.d., 12:160. For his arrival in Cairo, see Ibn Qād̄ī Šuhba, Ta'rīhn, 3:610f., cf. Ibn Hiğğğì, Tā'rīh, I, 227; Ibn Hağar, Inbā' al-Gumr, 3:327, gives with his arrival in Cairo the date "Gumādā II", which is probably the date of his destitution from office, certainly not that of his arrival in Cairo.

${ }_{133}$ Cf. Hallaq, W.B., "The qua di $\vec{\imath} \mathrm{s} d \bar{\imath} w \bar{a} n$ (sijill) before the Ottomans", BSOAS, 61 (1998), 415-436. 
judge collected together bundles of documents for this purpose: we know from literary sources ${ }^{134}$ and surviving texts ${ }^{135}$ that documents were issued in several versions and were given to the parties and to the judge. The judge then eventually transferred his dīwann to his successor. For the Mamlūk period, the Haram corpus may answer certain questions: given the number of documents that were issued every day by the witness-notaries in Jerusalem, it seems improbable that the judge received and filed a copy of each of them, at least not without using a filing system. ${ }^{136}$ And why should he personally keep all these documents? The bulk of the surviving specimens, estate inventories, were part of administrative procedures that concerned all adult persons at their death. They do not particularly record the $q \bar{a} d \vec{\imath}$ 's decisions.

In order to know what kind of "judge's records" were handed on to his successor, terminology is important. The Ayyubi judge Ibn Abi 1-Dam (d. 642/1244) says that the dīwān al-hukm containing mahädir and siğillāt was handed over to the successor who had to scrutinize (tasaffaha) whether the witnesses to these documents were still alive. In that case, there was no need to renew authentication (it $b \bar{a} t)$. However, if most witnesses were dead and only two of them alive, the judge had to summon them for authentication at his court. ${ }^{137}$

For Ibn Abī l-Dam, in other words, the body of the dīwān al-hukm seems to consist of certified documents. He describes how the successor of a $q \bar{a} d \bar{l}$ made sure, in the Ayyubid period, of the validity of his predecessor's decisions and certifications on the basis of documents that he had been given on becoming judge. In the Haram documents, the certification of a document at court (with or without a $h u k m$ ) was attested to by at least four court witnesses. The successor could then systematically examine these certifications and decide to renew certification according to how many of the court witnesses were still alive. It seems that these loose leaves of the dīwan al-hukm were stored in the qād $\vec{\imath}$ s qimatr, ${ }^{138}$ a repository for books or docu-

${ }^{134}$ Cf. Hallaq, "The $q \bar{a} d \vec{\imath}$ 's $d \bar{\imath} w \bar{a} n ", 420$, note 27.

${ }_{135}$ In inventories of the Haram corpus, I counted 97 notations such as nushatayn or $\underline{t} a l a \bar{t} \underline{n} n u s a h$, etc. Curiously enough, these specimens do not seem to bear a filing notation. See also below, note 154 , on inventories that exist in several exemplars.

${ }_{136}$ Only estate inventories bear filing notations within the Haram documents.

${ }_{137}$ Ibn Ab̄̄ 1-Dam, Šihāb al-Dīn Abī Ishāq Ibrāhīm, Kitāb adab al-qad̄a 'wa-huwa al-durar al-manzūmāt fì l-aqdiya wa-l-hukūmāt, M. al-Zuhaylī (ed.), Damascus, 1982 [1975], 122.

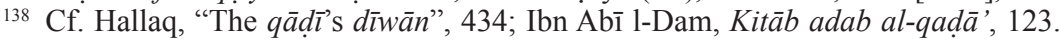

Al-Qanțara XXXII 2, julio-diciembre 2011, pp. 435-459 ISSN 0211-3589 
ments, after being filed and stamped. ${ }^{139}$ Holders of rights could ask for a copy. ${ }^{140}$ Haram document no. 333, a nushat kitāb concerning an endowment document that was certified during the years 712/May 1312-April 1313 to $754 / 1353$ by various succeeding judges ${ }^{141}$ might have been just such a copy issued on demand to the "holder of rights".

From Ibn Abī l-Dam's statement it seems clear that the qād $\vec{\imath}$ s archive which was handed down to his successor essentially contained certificate scrolls (siğillāt) ${ }^{142}$ and mahâdir that were probably also certified. ${ }^{143}$ The term mahädir (sing. mahdar), had several meanings and was probably more specific than "an official record of the minutes of a case or transaction conducted before a $q \bar{a} d \vec{\imath}$ ' ${ }^{144}$ Ibn Abi 1-Dam mentions the form beginning with the words šahida man ațbata ăhir hād $\bar{a}$ al-kitāb "according to notarial practitioners", 145 whereas his šāfi î teachers would also include court minutes (sūrat $\check{s}$ arh al-măglis) that begin with lammā kānā bi-ta'rīh. ${ }^{146}$ To what extent non-certified court minutes, like those of the Haram corpus, were included in the dīwān al-hukm is not clear from this statement.

139 Ibn Abī l-Dam, Kitāb adab al-qad̄à', 123.

140 Ibn Abī l-Dam, Kitāb adab al-qaḍà', 123.

${ }^{141}$ Cf. Little, Catalogue, 320.

142 This term, siğill, pl. siğillāt (scroll of certificates), is not synonymous with an is $\bar{g} \bar{a} l$, pl. is $\bar{g} \bar{a} l \bar{a} t$ (certification). A siğill contained several consecutive certifications (is $\breve{g} \bar{a} l \bar{a} t$ ), cf. Asyūțī, Ğawāhir al-'uqūd, 2:327. Contrary to Hallaq, "The qā Mamlūk author Nuwayrī (Šihāb al-Dīn Aḥmad, Nihāyat al-arab fì funūn al-adab, Cairo, s.d., 9:145-151), used the term is $\breve{g} \bar{a} l \bar{a} t$ (judicial certification) and not siğillät. The distinction made by Asyūṭ̂ between two forms of certification, is $\breve{g} \bar{a} l$ in Egypt and išhăd in Syria, 294f. (also ibid., 339), does not exclude the use of the term is $\breve{g} \bar{l}$ (certification) for non-Egyptian išh $\bar{a} d$ documents; cf. in the Haram documents, no. 15/2 and no. 371/2, 1. 13, or Muğìr al-Dīn, al-Uns al-ğalīl, 2:119 and 2:245. When Asyūṭī, Ğawāhir al-'uqūd, 2:393, says that the "mahdar is logically the basis (așl) of the sigill, the latter being constructed from the former", (translation by Hallaq, "The qua $d \vec{\imath} \mathrm{s} d \bar{\imath} w \bar{a} n ", 420)$ he clearly refers to scrolls of certificates, not to the notarization of a certification (isğa $\bar{a} l$ or išh $\bar{a} d$ ).

${ }^{143}$ Ibn Abī 1-Dam, Kitāb adab al-qad̄à', 122. Ibn Abī l-Dam's examples of a maḥִar include the attestation of procedure by court witnesses $(i s ̌ h \bar{a} d)$. In the Haram documents 150 years later, the attestation of court certification (išhad) is not part of the mahdar.

${ }_{144}$ Little's definition in the article "Sidjill.2", $E I^{2}$, IX, 539a.

${ }_{145}$ Cf. Ibn Abī l-Dam, Kitāb adab al-qadāa', 549, 551. This form is similar to the "Šahādāt" in the Haram corpus (Little, Catalogue, 249-259), which are often designated as mahdar in the court attestations on verso, cf. Müller, Qādì-Gericht, chapter I.2.a, on mahdar. Cf. examples in Nuwayrī, Nihāyat al-arab, 9:137ff.

'i46 Ibn Abī l-Dam, Kitāb adab al-qadā', 553f. The only Haram document of this kind that was certified and where we can verify terminology, no. 29/1, is designated on the verso as al-musațtar bātina-hu, i.e. not as a mahdar. Asyūṭ̂, Ğawāhir al-uqūd, 2:363f., also calls models of this kind mahdar.

Al-Qanțara XXXII 2, julio-diciembre 2011, pp. 435-459 ISSN 0211-3589 
The Ottoman court registers ${ }^{147}$ were organized differently and taken together functioned as a sigill (certificate): written mostly in chronological order in a codex, each entry of the register, whether it was a deed or any legal action, was evidence to what the court had authenticated at the registration date. As far as I can see, these Ottoman registry entries did not need a periodically renewed authentication after the death of court-witnesses, as Ibn Abī 1-Dam had postulated for the Ayyubid dīwān al-hukm.

The entry in an Ottoman court register corresponds in its legal function to the certified documents of the Haram corpus - with the notable difference that the latter were valid as a separate object. ${ }^{148}$ The mahâadir ${ }^{149}$ and "court records"150 of the Haram corpus are no exception to this rule. Surviving specimens seem not to be part of the dīwann al-hukm, since registration marks on mahädir and siğillāt to file the documents ${ }^{151}$ are missing on these Haram documents. ${ }^{152}$

${ }^{147}$ A survey in Faruqi, S., "Sidjill.3", $E I^{2}$, IX, 539a-544b. On the legal value of the Ottoman siğill, cf. Michel, N., "Registres de cadis d'Égypte (1743-1744) et notariat de Provence: pertinence d'une méthodologie comparative", in G. Audisio (ed.), L'historien et l'activité notariale. Provence, Vénétie, Égypte XVe-XVIIIe siècles, Toulouse, 2005, 225-252, 229-230.

${ }^{148}$ The individual certification of witness documents continued in Ottoman times. Cf. the certification of the waqfiyya of Șalāh al-Dīn for the Hānqāh al-Șalāhiyya in Jerusalem from Ayyubid until Ottoman times, as it was reproduced in the Ottoman sigill no. 95 on 2 Dū l-Hiğğa 1022/13 January 1614, in al- 'Asalī, K. Ğ., Watā 'iq maqdisiyya, 1:83-100, 97-100. For the Ottoman certifications, and, on a separate sheet, the certification of an acknowledgement (iqrār) on 8. Rabīe II 954/28 May 1547, and certified by the tribunal of Fašn on 27 Ğumādā II 956/23 July 1549, Berlin, Papyrussammlung P 24137, see my forthcoming edition and study of this document "Osmanische Gerichtsurkunden des 16. Jahrhunderts aus der Ägyptischen Provinz: Zu Kauf und Bezahlung einer Handelsladung hàlūm-Käse".

149 Designated in the certification as mahdar are mostly notarizations that Little calls "Šahādāat", cf. Little, Catalogue, 248-259. Cf. examples cited in Nuwayrī, Nihāyat al-arab, 9:137f. The certification process for some of them is consequently written on verso.

${ }^{150}$ Little, Catalogue, 261-273.

151 If the judges of Jerusalem followed Ibn Abī 1-Dam's recommendations, Kitāb adab al-qada ', 122f., which is not impossible given that the Haram documents also conform to other standards, then we have one more reason to think that the surviving specimen did not belong to the dīwän al-hukm that was handed down to the judge's successor. Haram document no. 883 might however be an exception and be, in fact, a Mamlūk siğill: it exclusively bears authentications of various is $\breve{g} \bar{a} l$ - and mahädirdocuments from the years 664-697 on an individual parchment to which other parts were added by sewing. Cf. Little, Catalogue, 239-242. I intend to publish this document.

${ }_{152}$ Contrary to Hallaq, "The $q \bar{a} d \vec{\imath}$ 's $d \bar{\imath} w \bar{a} n ", 431$, their physical existence does prove that they had to be part of a $q \bar{a} d \vec{\imath}$ s archive.

Al-Qanțara XXXII 2, julio-diciembre 2011, pp. 435-459 ISSN 0211-3589 
As shown above, we have no concluding evidence that the Haram documents constituted the judge's archive. They may have been a selection from documents he kept, but then why would he conserve several copies of the report on the cancellation of Muhibb al-Dīn's will, ${ }^{153}$ or copies of various estate inventories? ${ }^{154}$ All this is not intended to be an argument against the institutionalized existence of Mamlūk $q \bar{a} d \bar{l}$-records. Given the number of legal documents produced in a $q \bar{a} d \bar{l}$ tribunal and the sophistication of judicial administration, it would be astonishing to learn that no such institutions existed. However, we have no evidence that a chronological organized register of all ongoing affairs existed prior to the Ottoman period. The surviving Mamlūk documents containing single or repeated certification $(i s \bar{g} \bar{a} l / i s ̌ h \bar{a} d)$ of individual documents or on certificate scrolls (siğillāt), do not constitute a body of judicial documents (dīwān al$q \bar{a} d \bar{\imath}$ ) that was systematically copied and certified in its totality by a successor. ${ }^{155}$ The mystery of the Mamlūk $q \bar{a} d \vec{\imath}$ s archive is still unsolved.

Recibido: 17/05/2011

Aceptado: 30/05/2011

${ }^{153}$ Nos. 31, 32 and 650, see above.

154 The inventory of Yūsuf, on 10.12.795, exists in three exemplars (nos. 436, 441 and 720), and ten other inventories in two exemplars (in chronological order): Altinbug̀āā, 20.10 .793 (nos. 445 and 533); Sūmalik, 27.1.795 (nos. 168 and 592); Fātima, 26.6.795 (nos. 404 and 406), Țashhūn [?], 30.9 .795 (nos. 128 and 142), Maryam, 30.9.795 (nos. 444 and 473, Abū Bakr, 28.10.795 (nos. 694 and 696), 'Uțmān, 9.11.795 (nos. 515 and 626), Hawāğa Muhammad, 24.11 .795 (nos. 523 and 559), Fāṭima, 6.9.796 (nos. 262/1 and 624/1), 'Abd Aliāh, 23.11 .796 (nos. 237 and 537). Some of these doublets are indicated in Little, Catalogue. 425-7.

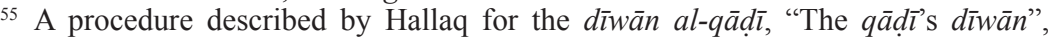

